\title{
PENGETAHUAN ORANG TUA TERKAIT PERTOLONGAN PERTAMA PADA KECELAKAAN YANG TERJADI PADA ANAK BALITA
}

\author{
Agus Khoirul Anam, Andi Hayyun Abiddin \\ Poltekkes Kemenkes Malang \\ Email :agus_khoirul@poltekkes-malang.ac.id
}

\begin{abstract}
Abstrak
Suatu kecelakaan atau keadaan darurat dapat menimpa siapa saja, tidak diduga, dan dapat terjadi kapanpun tanpa peringatan terlebih dahulu. Hal tersebut bersifat Kedaruratan yang artinya keadaan harus cepat diatasi, diberi pertolongan pertama, sekalipun belum tentu gawat yang mengancam jiwa. Tujuan penelitian menggambarkan pengetahuan orang tua tentang penatalaksanaan pemberian pertolongan pertama pada kecelakaan yang terjadi pada anak balita di rumah di Kelurahan Bendogerit Wilayah UPTD Kesehatan Kecamatan Sananwetan Kota Blitar. Metode penelitian menggunakan desain penelitian deskriptif. Populasi dalam penelitian ini adalah orang tua di Kelurahan Bendogerit Kecamatan Sananwetan Kota Blitar, jumlah sampel dalam penelitian ini adalah 55, diambil menggunakan teknik quota sampling. Hasil penelitian didapatkan responden memiliki tingkat pengetahuan baik sebanyak 35 orang (63.6 \%), cukup sebanyak $32.7 \%$ (18 orangtua) dan kurang sebanyak 3.6\% sebanyak (2 orangtua). Pengetahuan orangtua kurang dalam penatalaksanaan pertolongan pertama pada luka bakar, pengawasan anak saat bermain, dan penatalaksanaan pertolongan pertama saat tersengat listrik. Pemahaman prosedur mengenai pertolongan pertama pada kecelakaan di rumah perlu dikuasai orangtua agar dapat menurunkan resiko cedera pada anak balita.
\end{abstract}

Kata kunci : Pengetahuan, Orang tua, Kecelakaan, Anak

\begin{abstract}
Parental Knowledge Regarding First Aid In Accidents That Happened To Toddlers. An accident or emergency may happen to anyone, unexpectedly, and may occur at any time without warning. Emergency means circumstances must be quickly overcome, given first aid, though not necessarily life-threatening. Purpose of research Describes parents' knowledge about the management of first aid in accidents that occur in children under five at home in Bendogerit SubDistrict Health Unit UPTD Sananwetan District Blitar City. The research method used descriptive research design. The population in this research is parents in Bendogerit Sub-District Sananwetan Blitar City, the number of samples in this research is 55, taken using quota sampling technique. The results of parental knowledge about the management of first aid in accidents that occur in children under five at home are either as much as 63.6\% (35 parents), quite as much as $32.7 \%$ (18 parents) and less as much as 3.6\% as much (2 parents). Parents' knowledge is lacking in the management of first aid for burns, supervision of children while playing, and management of first aid when electrocuted. Understanding the procedure of first aid in an accident at home needs to be controlled by parents in order to reduce the risk of injury in children under five.
\end{abstract}

Keywords: Knowledge, Parents, Accidents, Children 


\section{Pendahuluan}

Kecelakaan atau keadaan darurat dapat menimpa siapa saja, dan dapat terjadi kapanpun tanpa peringatan terlebih dahulu. Kondisi darurat merupakan keadaan yang harus cepat diberi pertolongan, walaupun tidak mengancam jiwa. Apabila tidak segera ditolong dengan tindakan yang tepat dapat menjadi sesuatu yang gawat dan mengancam keselamatan jiwa korban. Situasi darurat seringkali menyebabkan kepanikan yang salah satu faktor penyebabnya adalah kurangnya pengetahuan (Syihabuddin, 2018). Sehingga meningkatkan pengetahuan terkait tata cara memberikan pertolongan pada kondisi kegawatan medis sangat penting.

Setiap tahun hampir 1 juta balita meninggal karena kecelakaan dan lebih dari puluhan juta anak-balita lainnya memerlukan perawatan rumah sakit karena mengalami luka berat di Indonesia (Daud \& Felizita, 2017). Kecelakaan yang sering terjadi adalah jatuh, terbakar, dan tenggelam yang pada umumnya terjadi di dekat rumah. Hal tersebut dapat dicegah dan dapat diatasi apabila orang tua mengetahui dan memahami apa yang harus mereka lakukan untuk mencegah kecelakaan dan bila kecelakaan sudah terjadi (Rachmawati, 2020). Tingkat pengetahuan orangtua yang rendah, sikap yang kurang baik dan tindakan ibu yang kurang tepat merupakan penyebab kejadian kecelakaan pada balita (Daud \& Felizita, 2017).
Saat ini, masyarakat masih memiliki kepercayaan kuno yang turun temurun dalam praktik pengobatan. Seperti halnya ketika anak terjatuh dan mengalami panas atau terkilir, dukun pijat menjadi pilihan alternatif pengobatan (Budi, 2012). Apabila terkena benda tajam langsung disiram menggunakan minyak tanah, bensin atau diberikan ramuan (bobok), masyarakat masih percaya hal tersebut dapat segera menghentikan perdarahan. Selain itu, saat anak mengalami panas tinggi diberikan kompres air dingin atau pemberian daun dadap untuk kompres diletakan di dahi dan saat terjadi keracunan, orang tua memberikan air kelapa hijau sebagai tindakan (Setijaningsih, 2020).

Dari fenomena diatas peneliti tertarik untuk meneliti tentang pengetahuan orang tua tentang penatalaksanaan pertolongan pertama kecelakaan yang terjadi pada anak balita di rumah dan penting untuk diteliti guna meningkatkan pengetahuan tentang keselamatan baik bagi anak, individu maupun keluarga.

\section{Metode}

Penelitian ini adalah penelitian deskriptif dengan desain Cross sectional. Populasi dalam penelitian ini adalah orang tua yang mengikuti posyandu balita yang balitanya terdaftar di dalam buku Kohort Posyandu di wilayah Puskesmas Pembantu 
Bendogerit sampel sebanyak 55 responden dengan teknik quota sampling. Pengumpulan data menggunakan lembar kuesioner yang disusun berdasarkan penelitian sebelumnya mengenai pengetahuan orang tua tentang resiko kecelakaan pada anak balita (Karunia \& Purwanti, 2011). Selanjutnya, peneliti melakukan uji validitas kepada 10 orangtua yang memiliki anak balita dan diasuh sendiri dengan kriteria yang sama, hasilnya bahasa kuesioner dapat dimengerti dan dipahami.

Peneliti mengajukan permohonan izin kepada Badan Kesatuan Bangsa Politik dan Penanggulangan Bencana Kota Blitar. Setelah surat ijin didapatkan, peneliti menyerahkan surat izin kepada Kepala UPTD Kesehatan Kesehatan Kecamatan Sananwetan Kota Blitar dan diteruskan ke Kecamatan Sananwetan dan dilanjutkan ke Kelurahan Bendogerit.

\section{Hasil}

Penelitian ini dilaksanakan di Posyandu Balita kelurahan Bendogerit Wilayah UPTD Kesehatan Kecamatan Sananwetan Kota Blitar. Pengumpulan data dilakukan pada Juni 2019 sesuai jadwal Posyandu. Analisa data secara deskriptif dengan tampilan persentase. Hasil pengumpulan data diuraikan dalam tabel dibawah ini.
1. Karakteristik Responden

Tabel 1. Karakteristik Responden

\begin{tabular}{|c|c|c|}
\hline Karakteristik & Frekuensi & Persentase \\
\hline \multicolumn{3}{|l|}{ Usia } \\
\hline $25-30$ & 27 & 49.1 \\
\hline $31-36$ & 16 & 29.1 \\
\hline$>36$ & 12 & 20.9 \\
\hline Total & 55 & 100 \\
\hline \multicolumn{3}{|l|}{ Pendidikan } \\
\hline SMP & 10 & 18.3 \\
\hline SMA & 30 & 54.3 \\
\hline Sarjana & 15 & 27.4 \\
\hline Total & 55 & 100 \\
\hline \multicolumn{3}{|l|}{ Agama } \\
\hline Islam & 50 & 91 \\
\hline Kristen & 5 & 9 \\
\hline Total & 55 & 100 \\
\hline \multicolumn{3}{|l|}{ Pekerjaan } \\
\hline PNS & 4 & 7 \\
\hline Wiraswasta & 12 & 22 \\
\hline IRT & 36 & 65 \\
\hline Lainnya & 3 & 6 \\
\hline Total & 55 & 100 \\
\hline \multicolumn{3}{|l|}{ Keterpaparan } \\
\hline \multicolumn{3}{|l|}{ Informasi } \\
\hline Pernah & 27 & 49 \\
\hline Tidak Pernah & 28 & 51 \\
\hline Total & 55 & 100 \\
\hline \multicolumn{3}{|c|}{ Sumber Informasi } \\
\hline Televisi & 13 & 23.6 \\
\hline Koran & 16 & 29.1 \\
\hline Petugas & 16 & 29.1 \\
\hline \multicolumn{3}{|l|}{ Kesehatan } \\
\hline Lainnya & 10 & 18.2 \\
\hline Total & 55 & 100 \\
\hline
\end{tabular}

Ket: PNS = Pegawai Negeri Sipil; IRT $=$ Ibu Rumah Tangga.

Berdasarkan tabel diatas, digambarkan bahwa sebagian besar responden berusia 25 30 tahun sebanyak 27 orang (49.1\%) dan pendidikan terakhir SMA sebanyak 25 orang $(45.1 \%)$. Selain itu, mayoritas responden beragama Islam sebanyak 50 orang (91\%) dan status pekerjaan sebagai IRT sebanyak 36 orang $(65 \%)$. Hampir sebagian besar tidak 
pernah mendapatkan informasi terkait pertolongan pertama kecelakaan pada anak balita di rumah sebanyak 28 orang (51\%).

2. Tingkat pengetahuan orang tua tentang pertolongan pertama kecelakaan pada balita

Tabel 2. Tingkat pengetahuan responden

\begin{tabular}{lcc}
\hline Pengetahuan & Frekuensi & Persentase \\
\hline Baik & 35 & 63.6 \\
Cukup & 18 & 32.7 \\
Kurang & 2 & 3.6 \\
Total & $\mathbf{5 5}$ & $\mathbf{1 0 0}$ \\
\hline
\end{tabular}

Berdasarkan tabel diatas diketahui bahwa pengetahuan orangtua tentang penatalaksanaan pertolongan pertama pada kecelakaan yang terjadi pada anak balita di rumah baik sebanyak 35 orang (63.6\%), sisanya cukup sebanyak 28 orang $(32.7 \%)$ dan kurang sebanyak 2 orang $(3.6 \%)$.

\section{Pembahasan}

Pengetahuan salah satu faktor yang menentukan perilaku seseorang karena pengetahuan akan membentuk kepercayaan dalam mempersepsikan kenyataan, memberikan orang tua dalam penatalaksanaan pertolongan pertama pada kecelakaan yang terjadi pada anak balita di rumah yaitu sebesar 63.7\% (35 orang) memiliki pengetahuan baik, 32.7\% (18 orang) memiliki pengetahuan cukup, dan $3.6 \%$ memiliki pengetahuan kurang (2 orang).
Pengetahuan merupakan hasil dari tahu dan tindakan dari mengingat suatu hal serta akan terjadi bila seseorang melakukan pengamatan terhadap suatu objek tertentu (Alfianur, 2020).

Pengetahuan yang baik dalam bisa dipengaruhi oleh beberapa faktor yaitu faktor internal dan eksternal. Faktor internal meliputi umur, intelegensi dan alat indra (Alfianur, 2020). Sedangkan faktor eksternal antara lain pendidikan, informasi, pengalaman, lingkungan, budaya, dan orang yang dianggap penting (Dewi, 2012).

Menurut Budi (2012) menyatakan bahwa pengetahuan terdiri dari berbagai tingkatan yaitu: tahu (know), memahami (comprehension), aplikasi (application), analisis (analysis), sintetis (synthesis), dan evaluasi (evaluation). Orang tua yang memiliki pengetahuan baik adalah orang tua yang sudah mengetahui, memahami dan dapat mengaplikasikan penatalaksanaan pertolongan pertama pada kecelakaan yang terjadi pada balita.

Disamping itu, sebanyak 51\% (28 orang) tidak pernah memperoleh informasi tentang pertolongan pertama pada kecelakaan. Kemudahan dalam mendapatkan informasi dapat membantu mempercepat seseorang untuk memperoleh pengetahuan yang baru, baik dari media elektronik 
maupun media cetak (Purwoko, 2016). Hal ini akan mempermudah orang tua untuk menambah wawasan tentang penatalaksanaan pertolongan pertama pada kecelakaan yang terjadi pada anak balita di rumah.

Sebagian besar responden memiliki pendidikan terakhir SMA sebanyak 54.3\% (30 orang) dan $27.4 \%$ (15 orang) memiliki pendidikan terakhir sarjana. Hal ini sesuai dengan penelitian yang menyebutkan bahwa makin tinggi tingkat pendidikan seseorang semakin mudah menentukan informasi dan makin banyak pengetahuan yang diperoleh, sebaliknya pendidikan yang kurang akan menghambat perkembangan sikap seseorang terhadap nilai baru yang diperkenalkan (Eva, 2013). Namun, pendidikan yang kurang menyebabkan daya intelektual yang masih terbatas. Hal tersebut dipengaruhi oleh keadaan lingkungan sekitarnya, budaya setempat, dan pengaruh orang lain yang menentukan pembentukan pengetahuan dalam diri seseorang (Hetty, 2020). Sehingga, pengetahuan yang baik pada orangtua mengenai penatalaksanaan pertolongan pertama pada kecelakaan yang terjadi pada anak balita di rumah sangat dipengaruhi oleh tingkat.

Selain pendidikan, pengalaman juga mempengaruhi tingkat pengetahuan seseorang (Winarti, 2019). Pengalaman merupakan suatu cara untuk memperoleh kebenaran pengetahuan, sehingga pengalaman pribadi dapat digunakan sebagai upaya untuk memperoleh informasi (Sumadi, Laksmi, Putra, \& Suprapta, 2020). Jadi apabila seseorang yang telah berpendidikan tinggi namun, belum pernah mempunyai pengalaman tentang pertolongan pertama pada kecelakaan yang terjadi pada anak balita dan tidak pernah terpapar informasi maka pengetahuannya belum bisa dijamin kebaikan (Saputro \& Jadmiko, 2017).

\section{Kesimpulan}

Berdasarkan hasil penelitian di atas dapat disimpulkan bahwa pengetahuan orang tua dalam penatalaksanaan pertolongan pertama pada kecelakaan yang terjadi pada anak balita di rumah baik sebanyak 35 orang $(63.6 \%)$.

\section{Saran}

Berdasarkan hasil penelitian, kami ingin menyampaikan saran, antara lain perlunya peningkatan pengetahuan melalui pemberian pelatihan dengan menjalin kerja sama dengan institusi pendidikan dibidang kesehatan. Selain itu, diharapkan orang tua berusaha dalam mencari informasi baik pelatihan maupun penyuluhan guna meningkatkan atau memperbarui pengetahuan melalui media massa, televisi, dan internet. 


\section{Referensi}

Alfianur, A. (2020). Pengetahuan Tentang Covid 19 Mahasiswa Keperawatan Universitas Borneo Tarakan. Journal of Borneo Holistic Health, 3(2).

Budi, U. (2012). Hubungan Antara Pengetahuan, Sikap Dan Tindakan Ibu Terhadap Kejadian Kecelakaan Balita Di Lingkungan Rumah Tangga Di Kecamatan Lawang Jawa Timur.

Daud, T., \& Felizita, E. (2017). Faktor-Faktor yang Berhubungan Dengan Perilaku Pencegahan Kecelakaan Pada Balita (Anticipatory Guidance) Di Wilayah Kerja Puskesmas Basuki Rahmad Kota Bengkulu Tahun 2016. Journal of Nursing and Public Health, 5(1), 11-15.

Dewi, A. W. M. (2012). Teori danPengukuran Pengetahuan, Sikap, dan Perilaku Manusia. Nuha Medika.

Eva, T. P. (2013). P3K Untuk Anak-Anak. We R Mommies Indonesia, Jakarta.

Hetty, N. (2020). Hubungan Pengetahuan Perawat Tentang Kegawatdaruratan Dengan Penanganan Primary Survey Pada Pasien Cedera Kepala Di Igd Rs Muhammadiyah Lamongan. Universitas Muhammadiyah Lamongan.

Karuni, A. T. S. W., Arifah, S., Skp, M. K., \& Purwanti, O. S. (2011). Hubungan Pengetahuan Ibu tentang Risiko Kecelakaan dengan Pencegahan Kecelakaan Anak Toddler di Posyandu Wilayah Kerja Puskesmas Combongan Sukoharjo, Universitas Muhammadiyah Surakarta).

Purwoko, H. (2016). Pertolongan Pertama untuk Anak.

Rachmawati, D. (2020). Assessment Dan Manajemen Trauma Pada Anak. Journal of Borneo Holistic Health, 3(2).

Saputro, W. W., \& Jadmiko, A. W. (2017). Pengaruh Pendidikan Kesehatan Dengan Metode Simulasi Terhadap Pengetahuan Dan Sikap Tentang Pertolongan Pertama Pada Kecelakaan
Di Smk Negeri 1 Mojosongo Boyolali. Universitas Muhammadiyah Surakarta.

Setijaningsih, T. (2020). Gambaran Pertolongan Pertama Dalam Keluarga Pada Penanganan Balita Diare Di Poli Mtbs Uptd Puskesmas Se-Kota Blitar. Journal of Borneo Holistic Health, 3(2).

Sumadi, P., Laksmi, I. A. A., Putra, P. W. K., \& Suprapta, M. A. (2020). Pengaruh Pelatihan Pertolongan Pertama Pada Kecelakaan Terhadap Pengetahuan Penanganan Fraktur Pada Anggota PMR Di SMP Negeri 2 Kuta Utara. Jurnal Keperawatan Muhammadiyah, 5(1).

Syihabuddin, R. (2018). Hubungan antara pengalaman, pengetahuan dan pelatihan dengan kesiapsiagaan tanggap darurat kebakaran di warehouse PT. VSL Indonesia. Universitas Binawan.

Winarti, W. (2019). Determinan Pengetahuan BHD dan Pertolongan Pertama Pada Guru Sekolah Dasar. Indonesian Journal of Health Development, 1(2). 